\title{
Developing Interactive Android-Based E-Learning Media as a Virtual Laboratory for the Students of Office Administration Education
}

\author{
Andi Basuki ${ }^{1}$, Umi Saiful Ummah ${ }^{2}$ \\ ${ }^{1}$ Faculty of Economics, Universitas Negeri Malang \\ ${ }^{2}$ Faculty of Education, Universiti Kebangsaan Malaysia, Malaysia \\ Email: andi.basuki.fe@um.ac.id
}

\begin{abstract}
The industrial revolution 4.0 leads to an increase in job competition. It should eventually be prepared with personal competence, especially for students in the Department of Office Administration Education. The current research developed interactive e-learning media as a virtual laboratory on a meeting organization course. This study aimed to examine the eligibility of the media and to know the response of the students. It employs Research and Development (R\&D) developed by Borg and Gall. The research model was modified to adapt to the limited time, energy, and cost. This virtual laboratory was designed with some attractive features such as meeting schedule, start the meeting, meeting minutes, content sharing, chat, meeting materials, meeting record, and contact. The current research product is e-learning media, an interactive virtual laboratory worth applying in the learning activities developed by the researchers. It is made based on the validation of the experts and the positive response of the students.
\end{abstract}

Keywords: Interactive E-Learning, Media Development, Virtual Laboratory

\section{INTRODUCTION}

Learning is an interactive process between learners, educators, and learning resources in the learning environment. Learning purpose is wholly achieved when the learning element is fulfilled (Irawan \& Djatmika, 2018), one of which is a medium for the learning process. The development of learning and teaching media should be tailored to the needs and the material presented (Sangsawang, 2015). Learning media is a part of learning resources that consists of a combination of software (learning materials) and hardware (learning tools) (Muhson, 2010). Education in Indonesia nowadays is heading to encourage the use of a wide variety of technology in the learning process. It can be acknowledged from some research studies on the development of learning media in Indonesia during the last five years (Divayana et al., 2017; Sulistyot et al., 2019; Wirawan \& Paryatna, 2018). Technology is used because it offers various convenience, and it has become a primary demand in the current global era. Akyuz and Yavuz (2015) also mentioned that technology becomes increasingly prevalent in the world of education. Hence, an expectation of utilizing technology as a teaching and learning support in the classroom arises among educators. Technology involvement in the learning process is expected to develop the students' competencies, along with learning objectives (Nafiah et al., 2019). 
Smartphones, as one of the products of technology, are perceived as a compatible tool for the learning process (Kim et al., 2019; The \& Usagawa, 2018). Many learning approaches are arranged through a smartphone-aided teaching program with several facilities, such as learning materials, modules for practicum, worksheets, tutorial video, even learning evaluation to determine the extent to which the effectiveness of the learning media developed. The practice of organizing a meeting requires a real laboratory office in which students can directly conduct a meeting. Meanwhile, the increasing number of students eventually accelerates the need for more laboratories. It must be complicated because building a laboratory office needs a high cost, and it requires quite an ample space. Therefore, a virtual laboratory for a meeting organization course is an alternative solution for the students of Office Administration Education. The development of virtual laboratories through smartphones is continuously increasing due to the cost, time, and security-friendly (Rahman et al., 2019). It is also supported by research conducted by Swandi et al. (2014) that learning through virtual laboratories can activate the learners and improve the students' understanding of the concept.

Virtual laboratory on meeting organization course is packaged with several exciting features, such as Meeting Schedule, Start the Meeting, Meeting Minutes, Meeting Materials, Chat, Content Sharing, Record the Meeting, and Contact. Besides, the virtual laboratory for the students of Office Administration Education is also equipped with a user guide on the front page of the application; therefore, they can practice independently. The use of a virtual laboratory as an alternative solution is expected to solve the university problems due to the limited number of laboratory office. Android-based smartphones, which are mostly owned by students, will be the media for fun learning, as it helps resolve the gap between the demand of the students and the fact that universities are could barely provide a sufficient laboratory office.

\section{METHODS}

The method employed in this study was Research and Development (R\&D). This method was used to produce specific products and to test the effectiveness of the products developed. It was assisted by the development model proposed by Gall et al. (1996). The development model was selected because the steps provided were easy to follow. Also, the research and development models of Gall et al. (1996) can produce a product or a model with a high-value validation because it was created through a series of trials in the field and validated by experts. The steps of the research and development are provided in Figure 1.

The subjects of the current study are students of the Department of Office Administration Education, Universitas Negeri Malang. The test was divided into two classes. A small group trial was performed to 10 students, and the large group one is distributed to 40 students. The data were collected by using a validation sheet from two experts and questionnaires from students. The validators of media development are media experts and material experts. 


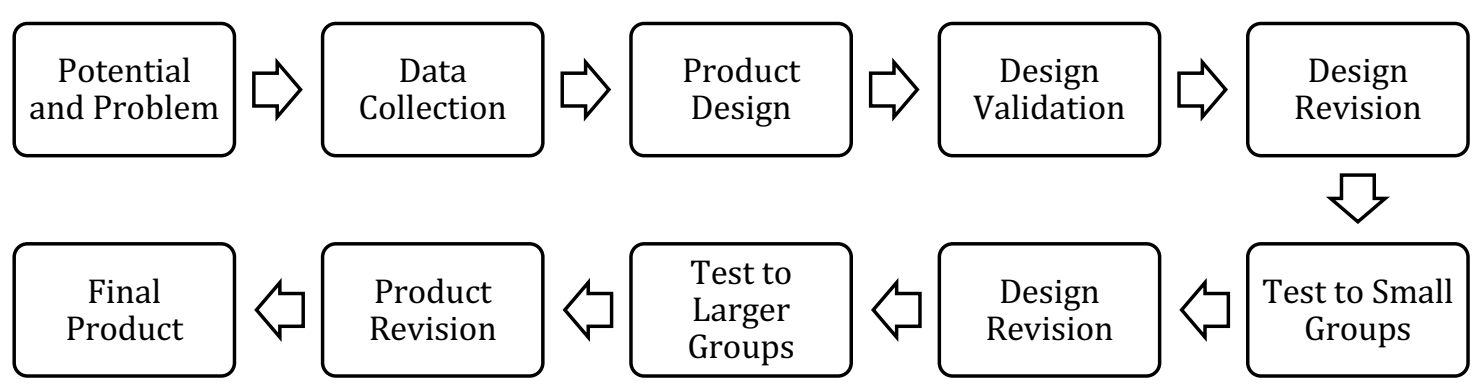

Figure 1. The Steps of Research and Development of Learning Media Source: Adapted from Gall et al. (1996)

Product validation was completed by presenting some experienced experts to assess the new product design (Sugiyono, 2017). This method was analyzed through qualitative and quantitative analysis; therefore, it generated balanced and accountable data. The qualitative analysis was performed on the validation sheet and the students' responses to the questionnaires. The researcher used a Likert scale in the process of expert validation. Likert scale was used to measure the attitudes, opinions, and perceptions of a person or group of people about social phenomena (Sugiyono, 2017). The alternative answers to every instrument using the Likert scale were graded from highly positive to highly negative. For the quantitative analysis, the answers to the questions were scored which provided in Table 1.

Table 1. The Indicator and Scoring Instruments

\begin{tabular}{|c|c|}
\hline Score & Indicator \\
\hline 5 & $\begin{array}{l}\text { If the statement in the column is entirely true, very appropriate, very easy, and very } \\
\text { interesting }\end{array}$ \\
\hline 4 & If the statement in the column is correct, appropriate, easy, and interesting \\
\hline 3 & If the statement is moderate, less appropriate, less easy, and less interesting \\
\hline 2 & if the statement is incorrect, inappropriate, uneasy, and uninteresting \\
\hline 1 & $\begin{array}{l}\text { if statement in the column is completely incorrect, very inappropriate, very uneasy, } \\
\text { and very uninteresting. }\end{array}$ \\
\hline
\end{tabular}

In addition, this study employed a percentage descriptive for analysis techniques, which transformed the quantitative data into a percentage and then interpreting it qualitatively. The formula used for data processing is:

\section{Information:}

$$
P=\frac{X}{X i} \times 100 \%
$$

$P \quad=\quad$ the percentage of the results of the subject test

$X \quad=$ the total of the answer scores by the subject test

$X i=$ the total of the maximum answers in the evaluation aspects of the subject

test

$100 \%=$ constant

The criteria for consideration of concluding are presented in Table 2. 
Table 2. Eligibility of the Media

\begin{tabular}{cl}
\hline Percentage & \multicolumn{1}{c}{ Criteria } \\
\hline $80 \%-100 \%$ & The media used are already eligible (no need to be edited) \\
$60 \%-79 \%$ & The media developed are quite eligible (partially edited when necessary) \\
$50 \%-59 \%$ & The media developed are less eligible (must be edited) \\
$<50 \%$ & The media developed is not eligible (must be edited) \\
\hline
\end{tabular}

Source: Sudjana and Rivai (2010); Suparti (2016)

\section{RESULTS \& DISCUSSION}

This research develops an interactive Android-based media for e-learning on a meeting organization course using the steps of the research and development by Gall et al (1996). Learning Media are used as a virtual laboratory for the students upon conducting a meeting. It aims to follow the rapid growth of today's technology and to let the students ready to go into the workplace directly, most of which have utilized technology. These Media are completed with various interesting features and user guide. The initial step in conducting the research and development of an application is finding the potential and problems. The potential is that every student has an Android smartphone that can be used to access the app developed by the researcher, and the problem is that not all the students have sufficient internet quota to access this application. The next step is to collect the data in the course outline and to analyze them for the product design.

This virtual laboratory was designed with some exciting features. The first feature is the Meeting Schedule, which functions to create a meeting agenda of when the meeting is conducted. We can also set the date, hour, and the contents of the meeting. It can also serve as a reminder of the meeting. The second feature is Start the Meeting, which functions to begin the meeting, either accidentally conducted or scheduled before. The third feature Meeting Minutes serves to record the courses of the meeting and the decision. This feature is also provided with a form to write the day, date, place, name of the moderator, the topic of the meeting, the list of participants, meeting agenda, the contents of the meeting, and the conclusion. The fourth feature is Content Sharing, which functions to share the content of the meeting, such as PowerPoint, website, or only a note. Chat is the fifth feature, which serves to facilitate the discussion among participants. It can also be used for the question and answer session. The sixth feature, Meeting Materials, covers the basic description about meeting such as definition, types, the terms, and conditions to conduct a good meeting, types of meeting leaders and participants, meeting preparation, and the material order of the meeting. The seventh feature is Record the Meeting, which serves to record all of the activities of the meeting from the beginning to the end. Lastly, the Contact feature contains all contact to call the meeting participants. The software application details of the virtual laboratory are shown in Figure 2. 


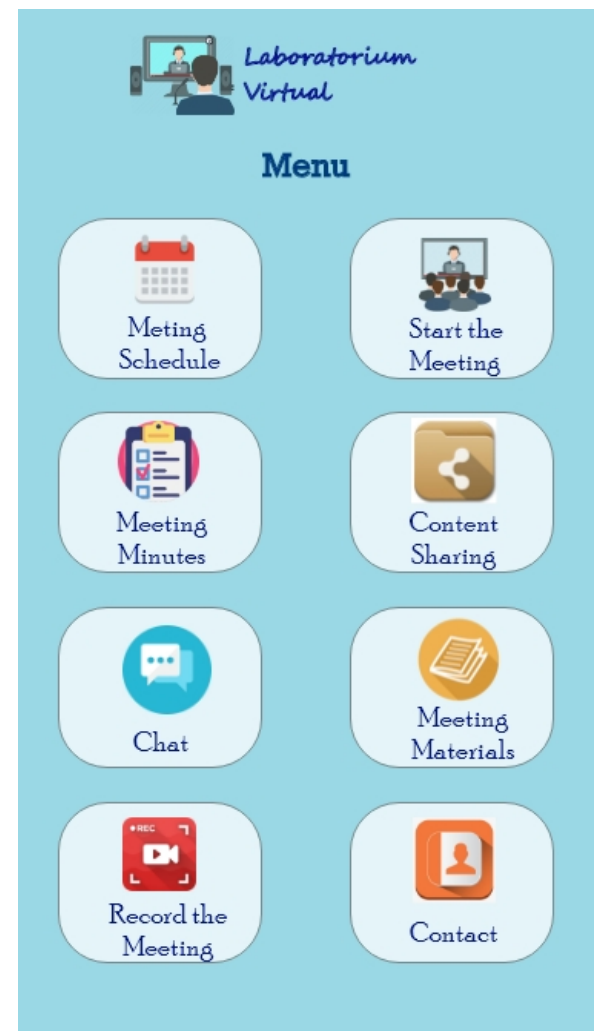

Figure 2. The Display of the Main Menu of the Virtual Laboratory

The eligibility of the interactive android-based E-learning as a virtual laboratory for students of Office Administration Educational was validated by material experts, media experts, and students. The validators assessed to decide whether the virtual laboratory is valid or not to be used as learning media on a meeting organization course. The media is considered valid if the experts claim that it is very eligible to be used as teaching media. It means that it is feasible to be used without revision or with few revisions. The results of the assessment/validation by the material and media experts are presented in Figure 3.

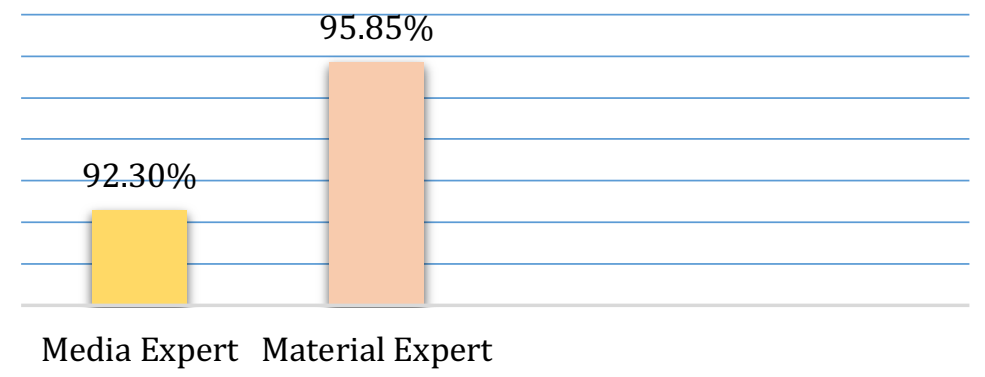

Figure 3. The Results of the Eligibility Validation by Media and Material Experts

Figure 3 shows that the virtual laboratory developed is feasible to be applied in the learning activities. The results of the questionnaire reveal that the media obtains 92.30 percent score from the media experts and 95,85 percent score from the material expert, exceeding 80 percent. The material and media experts said that 
the learning media had followed the materials of the meeting, and it is easy to be operated. These results indicate that the laboratory developed goes in line with the purpose of the course outline, easy to operate, and beneficial for the learning process. The virtual laboratory does not only improve the skills of the students but also increase their memory of the materials presented. It is in line with the previous research by Hikmah et al. (2017) that learning through virtual laboratory affects the students' understanding of the concepts of the reaction rate. Jagodzinski \& Wolski (2014) also mentions that learning through virtual laboratory can improve teaching efficiency. Students also can remember the materials faster and keep them longer. Furthermore, the results of the small and large group test are presented in Figure 4.

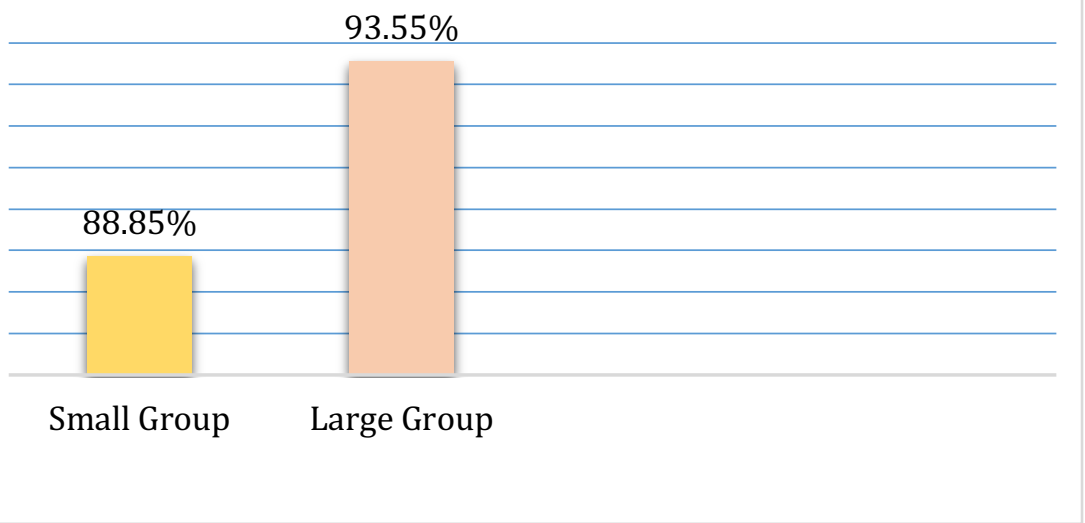

Figure 4. The Results of the Media Feasibility by Students

The test in the small group shows a lower percentage. They suggest a revision on the color and the font size of the writing for its nicer and neater look. That way, students get more interested in reading the materials provided in the virtual laboratory. Therefore, the media can affect the students' skills and way of thinking. The students' responses on the test to the small group are 88.85 percent, while that of the large one results in 93.55 percent. The results conclude that the media is feasible for the learning process because it reaches above 80 percent score. In this study, the students were interested in the look of the virtual laboratory. The media is easy to be operated. The material is also easy to be comprehended; thus, it provides fun learning. Yulianti et al. (2012) denote that the application of virtual laboratory-based learning can improve the affective skill of the learners, to describe the feelings, interests, and attitudes towards the learning process. Hermansyah et al. (2015) also argue that learning with a virtual laboratory can increase the students' mastery of the materials.

As supporting media for learning as stated by García-Peñalvo et al. (2014), that students nowadays are growing up with computers, mobile phones, and video consoles for almost every activity, including their learning activities. As a learning media development, a virtual laboratory has some benefits for teaching and learning activities. Some of them are (1) increasing students' competency which can be known from the students' ability to organize a meeting via the virtual laboratory, (2) improving the ability to cope with technology and contributing towards the pedagogical aspects (Jamieson-Proctor et al., 2013), as well as (3) giving students the opportunity for independent learning with specified time, place, and speed 
(Ozdamli \& Cavus, 2011). Although the results of this study indicate that the students see the virtual laboratory is eligible, it cannot claim that it is more effective than learning with the real laboratory. On the contrary, the virtual laboratory is made due to the limited equipment, time, and space.

\section{CONCLUSION}

Interactive android-based E-learning Media developed by the researcher is a virtual laboratory for the course of meeting organization for the students in the Department of Office Administration Education. The results of the validation performed by the material and media experts suggest that the media developed is highly feasible to be used in the learning process. They state that it has been in line with the materials of the meeting and easy to be operated. Meanwhile, the assessment towards the small and large group of students also indicates that the media is eligible to be used for learning. Further research is expected to produce a virtual laboratory in other courses that require a laboratory.

\section{REFERENCES}

Akyuz, S., \& Yavuz, F. (2015). Digital learning in EFL classrooms. Procedia-Social and Behavioral Sciences, 197, 766-769.

Divayana, D. G. H., Sappaile, B. I., Pujawan, I. G. N., Dibia, I. K., Artaningsih, L., Sundayana, I. M., \& Sugiharni, G. A. D. (2017). An evaluation of instructional process of expert system course program by using mobile technology-based CSE-UCLA model. International Journal of Interactive Mobile Technologies (iJIM), 11(6), 18-31.

Gall, M. D., Borg, W. R., \& Gall, J. P. (1996). Educational research: An introduction. Longman Publishing.

García-Peñalvo, F. J., González, M. Á. C., Zangrando, V., Holgado, A. G., Seoane, A. M., Forment, M. A., ... \& Mykowska, A. (2013). TRAILER project (tagging, recognition, acknowledgment of informal learning experiences) A Methodology to Make Learners' Informal Learning Activities Visible to the Institutions. J. UCS, 19(11), 1661-1683.

Hermansyah, H., Gunawan, G., \& Herayanti, L. (2017). Pengaruh penggunaan laboratorium virtual terhadap penguasaan konsep dan kemampuan berpikir kreatif siswa pada materi getaran dan gelombang. Jurnal Pendidikan Fisika dan Teknologi, 1(2), 97-102.

Hikmah, N., Saridewi, N., \& Agung, S. (2017). Penerapan Laboratorium Virtual untuk Meningkatkan Pemahaman Konsep Siswa. EduChemia Uurnal Kimia dan Pendidikan), 2(2), 186-195.

Irawan, C., \& Djatmika, E. T. (2018). Developing instructional media mobile learning based android to improve learning outcomes. Jurnal Pendidikan Bisnis dan Manajemen, 4(3), 107-113. 
Jagodzinski, P., \& Wolski, R. (2014). The examination of the impact on students' use of gestures while working in a virtual chemical laboratory for their cognitive abilities. Problem of Education, 61, 46-57.

Jamieson-Proctor, R., Albionn, P., Finger, G., Cavanagh, R., Fitzgerald, R., Trevor, B., \& Grimbeek, P. (2013). Development of the TTF TPACK survey instrument. Australian Educational Computing, 27(3), 26-36.

Kim, I., Kim, R., Kim, H., Kim, D., Han, K., Lee, P. H., Mark, G., \& Lee, U. (2019). Understanding smartphone usage in college classrooms: A long-term measurement study. Computers \& Education, 141, 103611. https://doi.org/10.1016/ j.compedu.2019.103611.

Muhson, A. (2010). Pengembangan media pembelajaran berbasis teknologi informasi. Jurnal Pendidikan Akuntansi Indonesia, 8(2).

Sudjana, N., \& Rivai, A. (2010). Media pengajaran. Jakarta: Remaja Rosdakarya.

Nafiah, U., Mashuri, M., \& Wijaya, D. N. (2019). The development of digital book of european history to shape the students' democratic values. International Journal of Emerging Technologies in Learning (iJET), 14(6), 147. https://doi.org/10.3991/ijet.v14i06.9760.

Ozdamli, F., \& Cavus, N. (2011). Basic elements and characteristics of mobile learning. Procedia - Social and Behavioral Sciences, 28, 937-942. https://doi.org/10.1016/j.sbspro.2011.11.173.

Sangsawang, T. (2015). Instructional Design Framework for Educational Media. Procedia-Social and Behavioral Sciences, 176, 65-80. https://doi.org/10.1016/ j.sbspro.2015.01.445.

Rahman, N. A., Ali, J. M., \& Baharom, M. (2019). Preliminary development of myaras: level 1 mobile virtual lab. International Journal of Emerging Technologies in Learning (iJET), 14(24), 131-139.

Sugiyono. (2017). Metode Penelitian Kuantitatif, Kualitatif, dan R\&D. Jakarta: CV. Alfabbeta.

Sulistyo, W. D., Nafi'ah, U., \& Idris, I. (2019). The development of e-pas based on massive open online courses (MOOC) on local history materials. International Journal of Emerging Technologies in Learning (iJET), 14(09). https://doi.org/10.3991/ijet.v14i09.10143.

Suparti. (2016). Metode penelitian pengembangan inovasi pembelajaran. Malang: UM Press.

Swandi, A., Hidayah, S. N., \& Irsan. (2014). Pengembangan media pembelajaran laboratorium virtual untuk mengatasi miskonsepsi pada materi fisika inti di SMAN 1 Binamu, Jeneponto. Jurnal Fisika Indonesia, 18(52), 20-24.

The, M. M., \& Usagawa, T. (2018). Investigation of students' mobile phone usage and influences towards their mobile learning adoption: a case study in Myanmar. International Journal of Interactive Mobile Technologies (iJIM), 12(5), 43. https://doi.org/10.3991/ijim.v12i5.8924.

Wirawan, I. M. A., \& Paryatna, I. B. M. L. (2018). The development of an Androidbased anggah-ungguhing balinese language dictionary. International Journal of Interactive Mobile Technologies (iJIM), 12(1), 4.

Yulianti, D., Khanafiyah, S., \& Sugiyanto. (2012). Penerapan virtual experiment berbasis inkuiri untuk mengembangkan kemandirian mahasiswa. Jurnal Pendidikan Fisika Indonesia, 8, 127-134. 